Research Article

\title{
Study of antinociceptive effect of paroxetine in acute pain in albino rats
}

\author{
Yatish B.*, Nadia Nausheen, Venkatesh M. Patil
}

Department of Pharmacology, Navodaya Medical College, Raichur, Karnataka, India

Received: 02 April 2016

Accepted: 07 May 2016

*Correspondence to:

Dr. Yatish. B,

Email: dr.yati1988@gmail.com

Copyright: (c) the author(s), publisher and licensee Medip Academy. This is an openaccess article distributed under the terms of the Creative Commons Attribution NonCommercial License, which permits unrestricted noncommercial use, distribution, and reproduction in any medium, provided the original work is properly cited.

\begin{abstract}
Background: Pain is an unpleasant sensory and emotional experience associated with actual or potential tissue damage or described in terms of such damage. In spite of having a number of drugs like NSAIDS and opioids for the management of pain, there is still need for an ideal analgesic agent with favourable safety profile. Many studies have shown that antidepressant drugs also have analgesic activity and particularly, selective serotonin reuptake inhibitors (SSRI) are effective in mixed and chronic pain. This study was done to evaluate antinociceptive effect of Paroxetine in albino rat and to compare antinociceptive effect of Paroxetine with the standard drug pentazocine in albino rat.
\end{abstract}

Methods: Animals were divided into five groups of six each, group I as control, group II as standard whereas groups III, IV and V as test groups (three doses). Antinociceptive effect of group II pentazocine $(10 \mathrm{mg} / \mathrm{kg}$ intraperitoneal $)$ and group III, IV and V received paroxetine $(2.5 \mathrm{mg} / \mathrm{kg}, 5 \mathrm{mg} / \mathrm{kg}$, and $10 \mathrm{mg} / \mathrm{kg}$ bodyweight intraperitoneally respectively) was evaluated in adult albino rats by Tail flick method.

Results: Mean RT after 120 minutes of injection of Paroxetine (10 mg) was higher than baseline value of 3.42 second with, mean difference $9.55 \pm 0.45$ and is significant when compared to control. No significant difference in RT was found between paroxetine $10 \mathrm{mg}$ and pentazocine $10 \mathrm{mg}$. No significant difference found when baseline reading was compared with 120 minutes readings of paroxetine 2.5 group.

Conclusions: Paroxetine, a SSRI antidepressant, has a clear antinociceptive activity.

Keywords: RT, SD, SSRI

\section{INTRODUCTION}

Pain is an unpleasant sensory and emotional experience associated with actual or potential tissue damage or described in terms of such damage. ${ }^{1}$ It is a protective mechanism, occurs whenever any tissues are being damaged, and it causes the individual to react and to remove the pain stimulus. ${ }^{2}$

\section{The pain can be classified as}

\section{Nociceptive}

Due to direct stimulation of peripheral nerve endings (e.g. wounds, fractures, burns, angina)

\section{Neuropathic}

Due to dysfunction of the pain perception system within the peripheral or central nervous system as a result of injury, disease or surgical damage (e.g. continuing pain experienced from a limb which has been amputated'phantom limb pain'). ${ }^{3}$

Pain has been a major concern of humankind since our beginnings, and it has been object of ubiquitous efforts to understand and control it. ${ }^{4}$

The task of medicine is to preserve and restore health and to relieve suffering. Understanding pain is essential to both of these goals. Because pain is universally understood as a signal of disease, it is the most common symptom that brings a patient to a physician's attention. 
The function of the pain sensory system is to protect the body and maintain homeostasis. It does this by detecting, localizing, and identifying potential or actual tissuedamaging processes. Because different diseases produce characteristic patterns of tissue damage, the quality, time course, and location of a patient's pain complaint provide important diagnostic clues. It is the physician's responsibility to provide rapid and effective pain relief. ${ }^{5}$

Pain is a symptom of many diseases requiring treatment with analgesics. ${ }^{6}$ It is the most common reason patients seek medical care. Analgesic medication is the first lines of treatment in pain management. ${ }^{7}$ Nonsteroidal antiinflammatory drugs (NSAIDs) are nonspecific analgesics and can potentially be used for any type of acute or chronic pain. Because they are both analgesic and antiinflammatory, the NSAIDs are among the most widely used of all therapeutic classes of drugs. ${ }^{8}$ Opioids are the most potent pain-relieving drugs currently available.

Furthermore, of all analgesics, they have the broadest range of efficacy, providing the most reliable and effective method for rapid pain relief. But their use limited by dose-related side effects like sedation, respiratory depression, pruritis, constipation and addiction liability on long term use. ${ }^{5}$

Most antidepressant medications are analgesics, and can relieve chronic pain even if the patient has no coexisting depression. The specific antidepressant effects are also important alleviating chronic depression is important in helping patients deal more effectively with pain. ${ }^{8}$

In spite of having a number of drugs for the management of pain, there is still need for an ideal analgesic agent with favorable safety profile.

Recently, numerous open and controlled studies have shown that antidepressant drugs also have analgesic activity and particularly, selective serotonin reuptake inhibitors (SSRI) are effective in mixed and chronic pain. $^{9}$

A study has shown that the increased level of monoamines (serotonin and norepinephrine) in synaptic clefts lead to changes in pain threshold and induce antinociception. ${ }^{10}$ The analgesic effect of selective serotonin reuptake inhibitor (SSRI) has been shown both in animal models and human cases suffering from different type of chronic pain. ${ }^{11}$ Because of numerous undesirable side effects of traditional tricyclics, the selective serotonin reuptake inhibitors (SSRIs), with a favorable side effect profile, are preferred. ${ }^{12}$

Paroxetine provided analgesic effect for patients with refractory chronic pain. However, this effect was remarkable with $20 \mathrm{mg}$ or more and accompanied by antidepressive effect. ${ }^{13}$
A study has shown that paroxetine improves pain symptoms in physical illness and it also revealed that there is evidence linking the analgesic properties of paroxetine with its serotonergic, opiodergic and noradrenergic activity. ${ }^{14-16}$

A study has shown that paroxetine improves pain symptoms in physical illness and it also revealed that there is evidence linking the analgesic properties of paroxetine with its serotonergic, opiodergic and noradrenergic activity. Among the various SSRIs, Paroxetine is most potent, hence used in this study. ${ }^{17}$

Despite of having such vast literature, it is not yet clear whether these can be used as analgesics and if so, what could be the underlying mechanism. Therefore the present study was designed with the aim of confirming the antinociceptive activity of one of the antidepressants, Paroxetine.

\section{METHODS}

Design of the study was quantitative experimental study in adult albino rats.

Settin in post graduate research laboratory, department of pharmacology, Navodaya medical college, Raichur according to ethical norms.

Wistar albino rats of either sex, weighing 150-200 g obtained from the national institute of nutrition, Hyderabad and maintained at central animal house of Navodaya medical college under suitable condition of housing, ventilation and nutrition were used for study. Animals were fasted overnight before experiment with free access to water.

Equipments used syringes, analgesiometer and stopwatch.

\section{Drugs}

Normal saline

Used as a control in the dose of $1 \mathrm{ml} / \mathrm{kg}$, administered by intraperitoneal route.

\section{Pentazocine}

Generic formulation is used as a standard drug in the dose of $10 \mathrm{mg} / \mathrm{kg}$, administered by intraperitoneal route.

\section{Paroxetine}

Paroxetine from biocon pharmaceuticals was used as test drug in the dose of $2.5 \mathrm{mg} / \mathrm{kg}, 5 \mathrm{mg} / \mathrm{kg}, 10 \mathrm{mg} / \mathrm{kg}$ administered by intraperitoneal route. 


\section{Experimental design}

For studying analgesic activity, animals were grouped into 5 groups (6 animals in each group), and treated I.P as follows;

- Group 1 (Control): received $1 \mathrm{ml} / \mathrm{kg}$ body weight of distilled water.

- Group 2 (Standard): received pentazocine $10 \mathrm{mg} / \mathrm{kg}$.

- Group 3 (Test): received paroxetine in a dose of 2.5 $\mathrm{mg} / \mathrm{kg}$ body weight.

- Group 4 (Test): received paroxetine in a dose of 5 $\mathrm{mg} / \mathrm{kg}$ body weight.

- $\quad$ Group 5 (Test): received paroxetine in a dose of 10 $\mathrm{mg} / \mathrm{kg}$ body weight.

The experiment was carried from 9 am to $1 \mathrm{pm}$. The study was conducted according to the ethical norms approved by the institutional animal ethics committee guidelines of Navodaya Medical College, Raichur.

\section{Tail flick method}

In this method rat tail is exposed to heated nicrome wire which provides thermal stimulus causing tail flick. It is widely and reliably used test for revealing the potency of analgesics. ${ }^{18}$ Initial reaction time (base line) for tail flick was noted in all the test animals. Reaction time is the time taken by the rat to withdraw its tail form the noxious stimulus.

\section{Statistical analysis}

One factor ANOVA followed by post-hoc Turkeys test was used for comparing groups with each other. ${ }^{19}$

\section{RESULTS}

For analgesiometer method reaction time was noted for tail flick before and 15 minutes, 30 minutes, 60 minutes, 120 minutes after injection of respective drugs.

Table 1: Comparison between control group and pentazocine group in analgesiometer method.

\begin{tabular}{|llllllll|}
\hline $\begin{array}{l}\text { Groups/drug- } \\
\text { time interval }\end{array}$ & \multirow{2}{*}{ Before } & \multicolumn{3}{c}{ After } & \multicolumn{3}{c|}{ Repeated measures anova } \\
\hline Control & $3.77 \pm 0.761$ & $3.75 \pm 0.543$ & $4.33 \pm 0.634$ & $4.55 \pm 0.538$ & $4.5 \pm 1.021$ & 0.6105 & 0.6599 \\
\hline Pentazocine & $4.27 \pm 1.058^{\# \#}$ & $7.83 \pm 0.754$ & $9.93 \pm 0.067$ & $9.43 \pm 0.442$ & $9.25 \pm 0.546$ & 20.600 & $<0.0001$ \\
\hline $\begin{array}{l}\text { Unpaired 't' } \\
\text { test }\end{array}$ & $\mathrm{T}$ & 0.384 & 4.392 & 8.779 & 7.012 & 4.101 & \\
\cline { 2 - 8 } & $\mathrm{P}$ & 0.7092 & 0.0014 & $<0.0001$ & $<0.0001$ & 0.0021 & \\
\hline
\end{tabular}

$\mathrm{n}=6$ in each group; latency in seconds for tail flick expressed as mean $\pm \mathrm{SEM} ; \mathrm{P}<0.05$ considered as significant; \#\#\# $\mathrm{P}<0.001$ when compared to $15 \mathrm{~min}, 30 \mathrm{~min}, 60 \mathrm{~min}$ and $120 \mathrm{~min}$ of pentazocine group.

There was no significant difference found when before reading was compared with 15 minutes, 30 minutes, 60 minutes and 120 minutes readings of the control group.

Thus, control group didn't produce the antinociceptive effect.

There was a significant difference found when before reading was compared with 15 minutes, 30 minutes, 60 minutes and $120(\mathrm{P}<0.001)$ readings of the pentazocine group $(\mathrm{P}<0.0001)$.

There was also a significant difference found when control group was compared with pentazocine group at all-time intervals i.e. 15 ( $\mathrm{P}=0.0014), 30(\mathrm{P}=<0.0001), 60$ $(\mathrm{P}<0.0001)$ and 120 minutes $(\mathrm{P}=0.0021)$.

Thus pentazocine produced a significant increase in the latency of tail flick at all-time intervals with onset producing within 15 minutes after the pentazocine injection and maximum antinociceptive effect producing at 30 minutes and 60 minutes and maintaining the effect till 120 minutes.

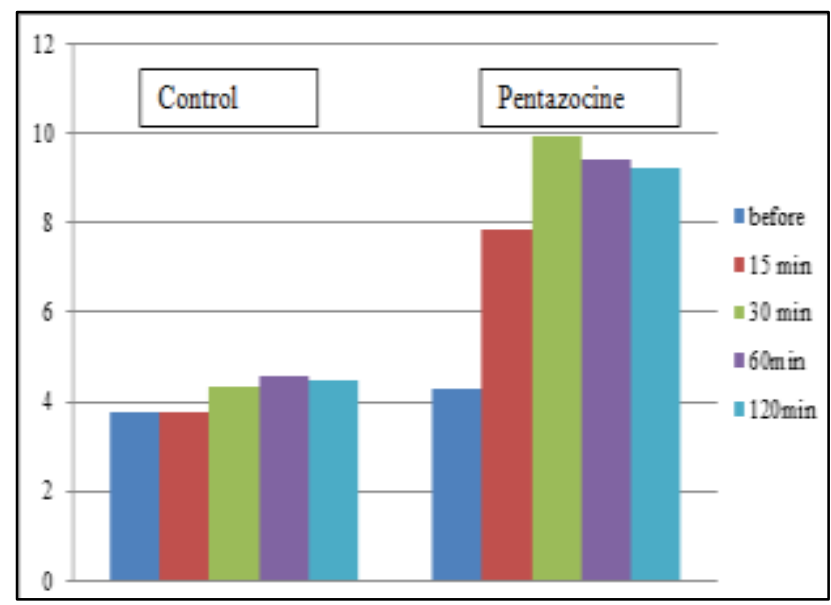

Figure 1: Graphical presentation of control and pentazocine. 
Table 2: Comparison among control, paroxetine 2.5, paroxetine 5 and paroxetine 10.

\begin{tabular}{|c|c|c|c|c|c|c|c|}
\hline \multirow{2}{*}{$\begin{array}{l}\text { Groups/drug- } \\
\text { time interval }\end{array}$} & \multirow[t]{2}{*}{ Before } & \multicolumn{3}{|c|}{ After } & \multicolumn{3}{|c|}{ Repeated measures anova } \\
\hline & & 15 minutes & 30 minutes & 60 minutes & 120 minutes & $\mathrm{F}$ & $\mathrm{P}$ \\
\hline Control & $3.77 \pm 0.761$ & $3.75 \pm 0.543 *$ & $4.33 \pm 0.634 * *$ & $4.55 \pm 0.538 * * *$ & $4.5 \pm 1.021$ & 0.6105 & 0.6599 \\
\hline Paroxetine 2.5 & $3.92 \pm 0.886$ & $5.17 \pm 1.094$ & $5.77 \pm 1.168 *$ & $6.78 \pm 0.703 *$ & $6.48 \pm 0.741 *$ & 1.994 & 0.1343 \\
\hline Paroxetine 5 & $2.3 \pm 0.384^{\# \# \#}$ & $7.37 \pm 0.773$ & $8.72 \pm 0.812$ & $8.95 \pm 0.627$ & $9.15 \pm 0.602 * *$ & 37.212 & $<0.0001$ \\
\hline Paroxetine 10 & 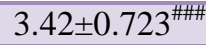 & $7.78 \pm 1.112$ & $9.35 \pm 0.650$ & $9.42 \pm 0.583$ & $9.55 \pm 0.450 * * *$ & 36.788 & $<0.0001$ \\
\hline One way & F 1.05 & 4.322 & 8.006 & 13.152 & 10.466 & & \\
\hline ordinary anova & $\mathrm{P} \quad 0.3921$ & 0.0166 & 0.0011 & $<0.0001$ & 0.0002 & & \\
\hline
\end{tabular}

$\mathrm{n}=6$ in each group; latency in seconds for tail flick expressed as mean \pm SEM; $\mathrm{P}<0.05$ considered as significant.

- $\quad$ Row 3: ${ }^{\# \#} \mathrm{P}<0.001$ when compared to 15 minutes, 30 minutes, 60 minutes and 120 minutes of paroxetine 5 group.

- Row 4: ${ }^{\# \# \#} \mathrm{P}<0.0001$ when compared to 15 minutes, 30 minutes, 60 minutes and 120 minutes of paroxetine 10 group.

- Column 2: *P<0.05 when compared to 15 minutes of paroxetine 5 and paroxetine 10 group.

- Column 3: $* \mathrm{P}<0.05$ when compared to 30 minutes of paroxetine 10 group.

$* * \mathrm{P}<0.01$ when compared to 30 minutes of paroxetine 5 and paroxetine 10 groups.

- Column 4: *P<0.05 when compared to 60 minutes of paroxetine 10 group.

$* * * \mathrm{P}<0.001$ when compared to 60 minutes of paroxetine 5 and paroxetine 10 group.

- Column 5: * $\mathrm{P}<0.05$ when compared to 120 minutes of paroxetine 10 group.

$* * \mathrm{P}<0.01$ when compared to 120 minutes of control group.

$* * * \mathrm{P}<0.001$ when compared to 120 minutes of control group.

There was no significant difference found when before reading was compared with 15 minutes, 30 minutes, 60 minutes and 120 minutes readings of paroxetine 2.5 group $(\mathrm{P}=0.1343)$.

There was a significant difference found when before reading was compared with 15 minutes, 30 minutes, 60 minutes and 120 minutes $(\mathrm{P}<0.001)$ readings of the paroxetine 5 group $(\mathrm{P}<0.0001)$.

There was a significant difference found when before reading was compared with 15 minutes, 30 minutes, 60 minutes and 120 minutes $(\mathrm{P}<0.001)$ readings of the paroxetine 10 group $(\mathrm{P}<0.0001)$.

At 15 minutes, there was significant difference found when control group was compared with paroxetine 5 $(\mathrm{P}<0.05)$ and paroxetine 10 group $(\mathrm{P}<0.05)$.

At 30 minutes, there was significant difference found when control group was compared with paroxetine 5 group $(\mathrm{P}<0.01)$ and paroxetine 10 group $(\mathrm{P}<0.01)$; and also there was significant difference found when paroxetine 2.5 group was compared with paroxetine 10 group $(\mathrm{P}<0.05)$.

At 60 minutes, there was significant difference found when control group was compared with Paroxetine 5 group $(\mathrm{P}<0.001)$ and paroxetine 10 group $(\mathrm{P}<0.001)$; and also there was significant difference found when paroxetine 2.5 group was compared with Paroxetine 10 group $(\mathrm{P}<0.05)$.

At 120 minutes, there was significant difference found when control group was compared with paroxetine 5 group $(\mathrm{P}<0.01)$ and paroxetine 10 group $(\mathrm{P}<0.001)$; and also there was significant difference found when paroxetine 2.5 group was compared with paroxetine 10 group $(\mathrm{P}<0.05)$.

Thus, paroxetine 2.5 didn't produce the antinociceptive effect while paroxetine 5 and paroxetine 10 produced the antinociceptive effect without dose dependently (both groups $\mathrm{P}$ value is $<0.0001$ ) but they differ in having the difference with paroxetine 2.5. Paroxetine 5 didn't show significant difference with paroxetine 2.5 at all-time intervals whereas paroxetine 10 showed significant difference with paroxetine 2.5 at 30 minutes $(\mathrm{P}<0.05), 60$ minutes $(\mathrm{P}<0.05)$ and 120 minutes $(\mathrm{P}<0.05)$.

Paroxetine 5 produced the antinociceptive effect with onset within 15 minutes after the injection and maximum effect at 60 minutes and maintaining the effect till 120 minutes.

Paroxetine 10 produced the antinociceptive effect with onset within 15 minutes after the injection and maximum effect at 60 minutes and 120 minutes.

There was no significant difference found when pentazocine group was compared with paroxetine 5 group and paroxetine 10 groups at all-time intervals.

There was also no significant difference found when paroxetine 5 groups were compared with paroxetine 10 group at all-time intervals. 
Thus, both paroxetine 5 and paroxetine 10 produced the antinociceptive effect statistically similar to pentazocine 10 at all-time intervals.

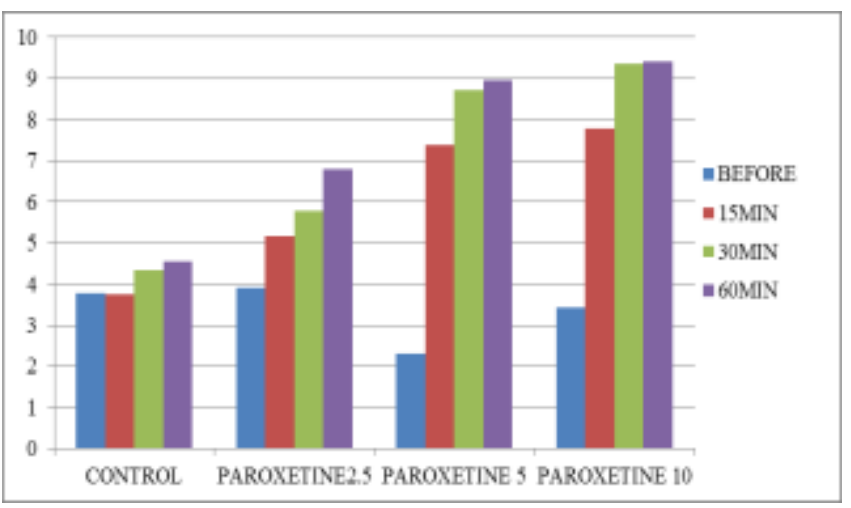

Figure 2: Graphical presentation among control group, paroxetine 2.5 group, paroxetine 5 group and paroxetine 10 group.

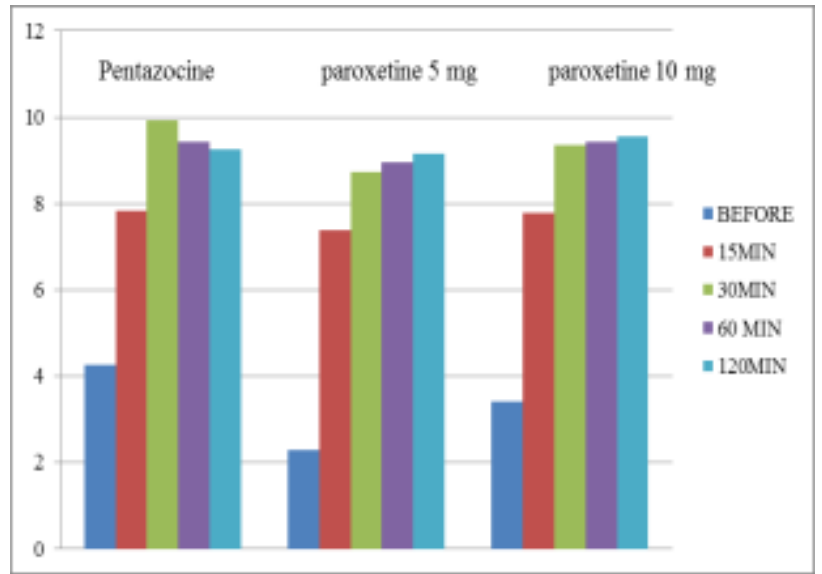

Figure 3: Graphical representation of comparison among pentazocine group, paroxetine 5 groups and paroxetine 10 group.

Table 3: Comparison among pentazocine group, paroxetine 5 group and paroxetine 10 group in analgesiometer method.

\begin{tabular}{|ll|llllll|}
\hline $\begin{array}{l}\text { Groups/drug-time } \\
\text { interval }\end{array}$ & Before & 15 minutes & 30 minutes & 60 minutes & 120 minutes & F & P \\
\hline Pentazocine & $4.27 \pm 1.058$ & $7.83 \pm 0.754$ & $9.93 \pm 0.067$ & $9.43 \pm 0.442$ & $9.25 \pm 0.546$ & 20.6 & $<0.0001$ \\
\hline Paroxetine 5 & $2.3 \pm 0.384$ & $7.37 \pm 0.773$ & $8.72 \pm 0.812$ & $8.95 \pm 0.627$ & $9.15 \pm 0.602$ & 37.212 & $<0.0001$ \\
\hline Paroxetine 10 & $3.42 \pm 0.723$ & $7.78 \pm 1.112$ & $9.35 \pm 0.650$ & $9.42 \pm 0.583$ & $9.55 \pm 0.450$ & 36.788 & $<0.0001$ \\
\hline $\begin{array}{l}\text { One way ordinary } \\
\text { anova }\end{array}$ & $\mathrm{F} 1.631$ & 0.082 & 1.023 & 0.243 & 0.1506 & \\
\cline { 2 - 8 }
\end{tabular}

$\mathrm{n}=6$ in each group; latency in seconds for tail flick expressed as mean $\pm \mathrm{SEM} ; \mathrm{P}<0.05$ considered as significant

\section{DISCUSSION}

In this study, the potential antinociceptive effect of paroxetine was evaluated.

The present study has shown that paroxetine has antinociceptive activity and it is almost equal to that seen with standard drug Pentazocine. The results of this study are consistent with that of study done by Erdem $\mathrm{N}$ et al. ${ }^{20}$

It is evident that, the reaction time increased in the all the groups significantly except in control and paroxetine 2.5 mg group. Hence it is evident that control and Paroxetine $2.5 \mathrm{mg}$ does not have any analgesic action. Whereas pentazocine 10 , paroxetine 5 and paroxetine 10 have significant analgesic action.

There is significant difference between values of group I when compared with group II, IV, and V indicating that pentazocine and paroxetine have significant analgesic action. This result was similar to the study conducted by Masand PS et al. ${ }^{21}$ There is no significant difference between group I and group III. When group II is compared with group $\mathrm{V}$, no significant difference was found showing that the test drug paroxetine 10 was similar to pentazocine in analgesic effect

\section{CONCLUSION}

Antidepressants, mainly tricyclic antidepressants have been found useful for the treatment of chronic pain. Because of numerous undesirable side effects of traditional tricyclic's, SSRIs with favourable side effects profile are preferred. Previous studies have put forward the possibility of SSRIs as a new group of analgesic drugs.

In view of this, we in our study have done the pre-clinical evaluation for antinociceptive effect of potent SSRI, paroxetine $(2.5 \mathrm{mg} / \mathrm{kg}, 5 \mathrm{mg} / \mathrm{kg}$ and $10 \mathrm{mg} / \mathrm{kg})$, its comparison with standard drug pentazocine $(5 \mathrm{mg} / \mathrm{kg})$ in acute pain, by using Analgesiometer by tail flick method analgesic models in swiss albino rat. 
The results of our study and the conclusions derived there are summarized as follows

\section{Paroxetine $2.5 \mathrm{mg} / \mathrm{kg}$}

Paroxetine $2.5 \mathrm{mg} / \mathrm{kg}$ in analgesiometer by tail flick method

Paroxetine 2.5 didn't produce the antinociceptive activity as compared to it's before reading and also as compared to control group.

Thus, these results will reflect that paroxetine 2.5 had no antinociceptive effect in analgesiometer method.

\section{Paroxetine $5 \mathrm{mg} / \mathrm{kg}$}

Paroxetine $5 \mathrm{mg} / \mathrm{kg}$ in analgesiometer by tail flick method

Paroxetine 5 had produced the antinociceptive activity as compared to it's before reading and also as compared to control and pentazocine group.

Thus, these results will tell us that paroxetine 5 had produced the antinociceptive effect in analgesiometer method statistically similar to pentazocine group.

\section{Paroxetine $10 \mathrm{mg} / \mathrm{kg}$}

Paroxetine $10 \mathrm{mg} / \mathrm{kg}$ in analgesiometer by tail flick method

Paroxetine 10 had produced the antinociceptive activity as compared to it's before reading and also as compared to control and pentazocine group. And there was no statistically significant difference found when compared to paroxetine 5 group.

Thus, these results suggest that paroxetine 10 had produced the antinociceptive effect statistically similar to pentazocine in both analgesiometer methods. There was no dose dependency found between paroxetine 5 and paroxetine 10. And also paroxetine 10 seems to be had better efficacy than paroxetine 5 as paroxetine 10 showing statistically similar antinociceptive effect as that of pentazocine in both the methods.

\section{ACKNOWLEDGEMENTS}

The authors would like to thank the following for their help and support during this project Mr. Narsimah for teaching me to handle mice and perform mice experiments. Dr. Ramabhimaiah. $\mathrm{S}$ for being a caring guidance. And lastly my parents, I can never repay their debt ever in this life.

\section{Funding: No funding sources}

Conflict of interest: None declared

Ethical approval: The study was approved by the Institutional Ethics Committee

\section{REFERENCES}

1. Russo M, Cathy M, Brose M, William G. Chronic pain. Annual review of medicine. 1998;49(1):123-33.

2. Becker D. Pain management in adult dental patients: the art and science of successful regimens. Practical periodontics and aesthetic dentistry. PPAD. 1996;8:1.

3. Oxenham D. Davidson's principles and practice of medicine. $21^{\text {st }}$ ed: Churchill Livingstone Elsevier; 2010:280.

4. Guyton AC, Hall JE. Text book of medical physiology. $10^{\text {th }}$ ed: Philadelphia: Sauders; 2000:552.

5. Fields HL, Martin JB. Pain pathophysiology and management. In: Harrison's Principles of Internal Medicine. $17^{\text {th }}$ ed.: Volume I; McGraw-Hill Companies, United States of America; 2007:81-86.

6. Vogel HG, Vogel WH, Schölkens BA, Sandow J, Müller PDG, Vogel WF. Analgesic, antiinflammatory, and anti-pyretic activity. Drug Discovery and Evaluation: Springer; 2002:670-773.

7. Lowensten DH. Pain: pathophysiology and management. In: Fields HL, Martin JB edts Harrisons principles of internal medicine. $16^{\text {th }}$ edn, Volume I, Unite states of America: Mc Graw Hills Companies; 2005:7.

8. Elhwuegi AS, Hassan KM. The analgesic effect of different antidepressants combined with aspirin on thermally induced pain in Albino mice. Libyan Journal of Medicine. 2012;7(1):17251.

9. Jung AC, Staiger T, Sullivan M. The efficacy of selective serotonin reuptake inhibitors for the management of chronic pain. Journal of general internal medicine. 1997;12(6):384-9.

10. Yokogawa F, Kiuchi Y, Ishikawa Y, Otsuka N, Masuda Y, Oguchi K, et al. An investigation of monoamine receptors involved in antinociceptive effects of antidepressants. Anesthesia and analgesia. 2002;95(1):163-8.

11. Duman EN, Kesim M, Kadioglu M, Yaris E, Kalyoncu NI, Erciyes N. Possible involvement of opioidergic and serotonergic mechanisms in antinociceptive effect of paroxetine in acute pain. Journal of pharmacologi al sciences. 2004;94(2):161-5.

12. Richelson E, editor. Pharmacology of antidepressants. Mayo Clinic Proceedings; Elsevier. 2001;76:511-27.

13. Kanai A, Hoka S. Analgesic and antidepressive effect of paroxetine in patients with refractory chronic pain. Anaesthesiol. 2005;103:753.

14. Masand PS, Narasimhan M, Patkar AA. Paroxetine for somatic pain associated with physical illness: a review. Primary care companion to the Journal of clinical psychiatry. 2006;8(3):122-30.

15. Gray A, Spencer P, Sewell R. The involvement of the opioidergic system in the antinociceptive mechanism of action of antidepressant compounds. British journal of pharmacology. 1998;124(4):669-74.

16. Gray AM, Pache DM, Sewell RD. Do $\alpha 2$ adrenoceptors play an integral role in the 
antinociceptive mechanism of action of antidepressant compounds? European journal of pharmacology. 1999;378(2):161-8.

17. Ghosh MN. Fundamentals of Experimental Pharmacology. $4^{\text {th }}$ ed. Kolkata: Ghosh SK; 2008:73.

18. Turner RA. Analgesics in: screening methods in pharmacology; Academic press Newyork London; 1985.

19. Rao KV. Biostastics a manual of statistical mehods for use in health, nutrition and anthropology. $1^{\text {st }}$ edn, Mumbai: Jaypee; 1996:237,278.
20. Erdem DN, Murat K, Mine K, Cunay U, Nuri KI, Ersin Y. Effect of gender on antinociceptive effect of paroxetine in hot plate test in mice. Prog neuro psychopharmacol Biol Psychatr. 2006;30(2):292-6.

21. Masand PS, Narasimhan M, Patkar AA. Paroxetine for somatic pain associated with physical illness: A review. Prim Care Companion J Clin Psychiatry. 2006;8:122-30.

Cite this article as: Yatish B, Nausheen N, Patil VM. Study of antinociceptive effect of paroxetine in acute pain in albino rats. Int $\mathbf{J}$ Basic Clin Pharmacol 2016;5:1022-8. 